\title{
Monetary and absorption approach to explain the Croatian current account ${ }^{*}$
}

\author{
Mile Bošnjak ${ }^{1}$ Ivan Novak ${ }^{2}$, Ante Krišto ${ }^{2}$
}

\begin{abstract}
The paper brings the determinants of Croatian current account dynamics under monetary and absorption approach. The main hypothesis of the paper assumes that Croatian current account can be explained within the framework based on the monetary and absorption approach to balance of payments. The research employed newly developed Non-linear Auto-Regression Distributed Lag (NARDL) approach that takes into account nonlinear and asymmetric nature of the relationship between Croatian current account and its determinants. Estimated results on a quarterly data sample from the first quarter of 2000 to the second quarter of 2017 supports the main research hypothesis and reveals that that Croatian current account can be explained using the analytical framework based on the monetary and absorption approach. Domestic demand, real exchange rate index, loans to private sector and monetary aggregates M4 are tested as the determinants of Croatian current account. Monetary aggregates M4 are found to hold the highest explanatory power among tested monetary variables. The main findings of the paper suggest the need for fiscal policy measures and relaxing the liquidity constraints for the Croatian exporters as necessary to obtain external equilibrium.
\end{abstract}

Key words: asymmetric cointegration, current account, monetary approach, absorption approach, Croatia

JEL classification: C22, C51, F14, F43

\footnotetext{
Received: 02-05-2018; accepted: 12-12-2018

1 Assistant Professor, University of Zagreb, Faculty of Economics and Business, Trg J. F. Kennedyja 6, 10000 Zagreb, Croatia. Scientific affiliation: international economics, nonlinear econometrics, applied econometrics, neural networks.

2 Student assistant, back. oecc. University of Zagreb, Faculty of Economics and Business, Trg J. F. Kennedyja 6, 10000 Zagreb, Croatia. Scientific affiliation: international finance.
} 


\section{Introduction}

Croatia experienced trade and financial liberalization in a last two and half decades and eventually joined the European Union (EU). The current account deficit in Croatia and other similar countries persisted until recently. One stand of literature explain the current account deficit of European transition countries by growth in domestic demand financed by the inflow of foreign loans and real appreciation of domestic currencies (Aristovnik, 2008; Zakharova, 2008; Bakker and Gulde, 2010; Obadić et al., 2014). Impavido et al. (2013) reported that banks in Central, Eastern and South Eastern Europe have experienced reduction of foreign funding sources in response to reduced external imbalances since the financial and economic crisis of 2008. Bilas and Bošnjak (2015) examined of international trade between Croatia and the rest of the EU member countries and found that trade patter as suggested by Heckscher-Ohlin trade theorem while Croatia appeared as the labour abundant country. Furthermore, Bošnjak et al. (2018) pointed out that merchandise trade between Croatia and other EU member countries was unsustainable. Wollmershäuser (2016) proposed gradual and managed currency depreciation as a solution to improve price competitiveness and obtain external sustainability of the Croatian economy. The aim of the paper is twofold. The main aim of the paper is to explain the dynamics of the balance of payments in case of Croatia and identify appropriate potential policy measures accordingly. Additionally, the paper aims to examining the competing theories of international economics in case of small and euroized post-transition economy. Consistently, the goal of the paper is to identify the determinants of the balance of payments in the case of Croatia while taking into account the possible nonlinear nature of the relationship between balance of payments and its determinants.

This paper examines the Croatian current account in lights of monetary and absorption approach. The main idea of absorption approach is that current account will improve if its output of goods and services increases by more than its absorption (Harberger, 1950). The monetary approach pointed out demand and supply of money and its relationship as the one that determines current account balance (Polak, 1957). It is reasonable to assume that the former as well as the latter approach contributes to explain the dynamics in the Croatian current account. Consequently, the research hypothesis of the paper states that the Croatian current account can be explained within the analytical framework based on the monetary and absorption approach.

The remainder of this paper is organized as follows: Section 2 briefly summarizes baseline theoretical framework and existing literature related to the topic under consideration. Section 3 presents methodology, while Section 4 empirical data and analysis. The Section 5 provides research results and discussion and final section provides an overview of the main findings of the research. 


\section{Literature review}

Theories of international economics offer several approaches to explain the balance of payments. The baseline theory observed a real depreciation of the currency and corresponding effects on the current account balance of a country (Robinson, 1937). The effects of a real depreciation of the currency were found to be conditional and literature recognized the condition as the Marshall-Lerner condition. The condition states that if the absolute sum of the long-term elasticities of import demand and export supply is greater than unity, the exchange rate depreciation will improve the current account balance of a country. The literature refers the corresponding approach as the elasticity approach to the balance of payments. Bahmani et al. (2013) provided an extensive overview of the elasticity approach to the balance of payments along with estimates of long-run import and export elasticities for 29 countries. The elasticity approach was blamed to neglect the income and expenditure effects of exchange rate changes (Thirlwall, 1980) and to compensate limitations of the elasticity approach Alexander (1959) introduced the absorption approach to balance of payments. The absorption approach observes the effects of a real depreciation of the currency on the current account balance but takes into account national income and reformulates the condition. Following the absorption approach, the effects of currency depreciation on the balance of payments depend on the consequent change in the income of the country. Hence, the balance of payments represents the difference between national income and national expenditure. Therefore, within the absorption approach correction policy can be evaluated in terms of whether it raises national income relative to national expenditure. Monetary approach originally suggested by Polak (1957) regards balance of payments as a monetary phenomenon and points out the role of supplies of and demands for money. Following the monetary approach, deficit or surplus in balance of payments arises out of disequilibrium between demand and supply in the money market. Furthermore, the demand for money can be satisfied from internal sources through credit creation or from external sources through the balance of payments. Following the monetary approach, excessive supply over demand for money will cause the deficit in balance of payments. Each of the presented approaches comes with its own assumptions and constitute analytical framework to analyse the balance of payments. Empirical literature from various countries and regions supported the presented approaches but there were always the one or two approaches that dominated. Therefore, empirical literature is ambiguous in regards the dominant approaches to explain balance of payments and finding the appropriate theoretical explanation for a specific country or region represents the empirical issue.

Kovačević (2017) employed panel data approach and examined the relation between the current account balance and its determinants for a sample of nine Southeast European (SEE) countries, namely Bulgaria, Croatia, Romania, Moldova, Serbia, Bosnia and Herzegovina, Macedonia, Montenegro, and Albania. The findings indicate that current account deficit persisted under pressure of real effective 
exchange rate while the effects from net inflow of foreign direct investments (FDI) to current account were found to be positive for the considered countries. Ozgur and Memis (2017) examined the trade deficits of the eleven Eurozone - countries and explained the trade deficit of sample countries by credit expansion and asset prices while no significant effects was reported for countries with trade surpluses. Shahid Hassan et al (2017) employed ARDL bound testing to examine the determinants of trade deficit in Pakistan, India and Bangladesh and found real effective exchange rate, per capita income and money supply as the significant determinant of trade flows for the considered countries. Davis et al. (2016) pointed out that combination of credit growth and external deficits increases the probability of a banking crisis. Ekinci et al. (2015) suggest that at the early stages of financial development, acceleration in the credit growth might cause deterioration in the current account. Elhaddadi and Karim (2017) examined the Moroccan case under monetary approach (Polak, 1957) and reported the theoretically consistent adjustment. Khalid Yousif and Attahir Musa (2017) employed VECM approach in its linear specification form to examine the determinants of Sudan balance of payments and reported the significant role of foreign debt, inflation, gross domestic product and exchange rate. Meniago and Hinaunye Eita (2017) reported the significant role of exchange rate changes for imports, exports and trade balance in Sub-Saharan Africa but the response is found to be extremely low. Chukuet al. (2017) examined the long-run and short-run determinants of current account balances in West Africa and reported different shortrun and long-run determinants. Unger (2017) pointed out that bank loans to the nonfinancial private sector were a significant determinant of the current account in the countries with current account deficit. Following the extensive overview of empirical literature, Kauko (2014) pointed out that during a typical build-up phase, domestic banks borrow internationally to finance domestic lending and consequently boosting the current account deficit. Some recent papers reported nonlinear and regime dependent dynamics in trade flows (Khadaroo, 2016; Topalli and Dogan, 2016). Fasanya and Olayem (2018) followed Thirlwall's BOP-constrained growth approach and analysed the case of Nigeria. The results revealed the constraints to economic growth of Nigeria arising from balance of payments. The suggested policy included strengthening of macroeconomic stability and institutional qualities, improvement in human and physical capital development and reducing access problems to external market. Conclusively, this paper contributes to the existing literature with Croatian case while taking into account the possible nonlinear and asymmetric relationship between Croatian current account and its determinants.

\section{Methodology}

The analysis in this paper is based on time series data and takes into account the possible nonlinear and asymmetric relationship between the Croatia current account and its determinants. Firstly, using standard unit root test (ADF, PP, KPSS) 
the variables are tested for existence of unit root and insights into property of stationarity are provided for the observed series. Here needs to be stated that the Non-linear Autoregression Distributed Lag (NARDL) approach we follow in this paper requires that all of the observed variables are stationary I (0) or integrated of order one I (1). NARDL approach developed by Shin et al. (2011) is employed in this paper in order to take into account the nonlinear relationship between the Croatian current account and variables under consideration. In the NARD approach we follow in this paper the short - run and long-run nonlinearities are introduced through positive and negative partial sum decompositions of the explanatory variables. As already stated and contrary to standard linear co-integration approach, this model specification does not depend on the degree of the integration of the variables.

So, the increase $\left(X_{i t}^{+}\right)$and decrease $\left(X_{i t}^{-}\right)$of the independent variables $\left(X_{i t}\right)$ can be defined with the application of partial sum process as given by the equations (1) and (2).

$$
\begin{aligned}
& \mathrm{X}_{i t}^{+}=\sum_{j=1}^{t} \Delta \mathrm{X}_{i_{j}}^{+}=\sum_{J=1}^{t} \max \left(\Delta \mathrm{X}_{i_{j}}, 0\right) \\
& \mathrm{X}_{i_{t}}^{-}=\sum_{j=1}^{t} \Delta \mathrm{X}_{i_{j}}^{-}=\sum_{J=1}^{t} \min \left(\Delta \mathrm{X}_{i_{j}}, 0\right)
\end{aligned}
$$

Firstly, NARDL model is employed to obtain the estimates for the absorption approach only and the model specification is given by the equation (3):

$$
\begin{aligned}
& \Delta \mathrm{CA}_{\mathrm{t}}=\alpha_{0}+\beta_{1} \mathrm{CA}_{\mathrm{t}-1}+\beta_{2} D_{t-1}^{+}+\beta_{3} D_{t-1}^{-}+ \\
& \sum_{i=1}^{p-1} \gamma_{i} \Delta \mathrm{CA}_{\mathrm{t}-\mathrm{i}}+\sum_{i=1}^{q} \delta_{i}^{+} \mathrm{D}_{t-i}^{+}+\sum_{i=1}^{q} \delta_{i}^{-} \mathrm{D}_{t-i}^{-}+\varepsilon_{t}
\end{aligned}
$$

Similarly, the model specification is extended using various variables representing the monetary sector (real effective exchange rate index, loans to private sector and monetary aggregates M4). Pesaran et al. (2001) developed the approach to the problem of testing the existence of a level relationship between a dependent variable and a set of independent variables, when it is not known with certainty whether the underlying independent variables are trend stationary or stationary in its first-difference. The tests are based on standard $\mathrm{F}$ and $\mathrm{t}-$ statistics employed to test the significance of the lagged levels of the variables in a univariate equilibrium correction mechanism. The asymptotic distributions of these statistics are non-standard under the null hypothesis that there exists no level relationship, irrespective of whether the independent variables are I (0) or I (1). The testing procedure relies on two sets of asymptotic critical values. The one for the case if all independent variables are purely I (1) and the other if the independent variables are all purely I (0). The two sets of critical values provide critical value bounds for all classifications of the independent variables into purely I (1), purely I (0) 
or mutually cointegrated and if the computed Wald or F-statistic falls outside the critical value bounds, a conclusive inference can be drawn without needing to know the integration of the independent variables. After the NARD model estimates are obtained, following Pesaran et al. (2001) the long run and short run asymmetric effects are tested. Eventually, using standard diagnostic tests, namely ARCH Test, Breusch-Godfrey Serial Correlation LM Test and Jarque-Bera Test $t$ are performed for each of the estimated model.

\section{Empirical data and analysis}

The research is based on the quarterly data on imports, exports, domestic demand, real effective exchange rate index, loans to private sector and monetary aggregates M4 from the first quarter of 2000 to the second quarter of 2017. The imports, exports and domestic demand series are obtained from Croatian Bureau of statistics while real effective exchange rate index, loans to private sector and monetary aggregates M4 series are obtained from Croatian National Bank. The observed series that represent current account in this paper $(C A)$ is given by the equation (4):

$$
\mathrm{CA}=\frac{\mathrm{EXP}}{\mathrm{IMP}}
$$

where IMP represents the level of import and EXP the level of exports.

Domestic demand over Gross Domestic product (GDP) is represented by the variable D. Loans to private sector over GDP and monetary aggregates M4 over GDP are represented by the variables LTPS and M4, respectively. Real effective exchange rate index is denoted by the variable REER All of the variables under consideration are X-13 ARIMA seasonally adjusted and taken in (natural) log values. Following the procedure described in the section methodology, unit root tests results are summarized in Table 1. 
Mile Bošnjak et al. - Monetary and absorption approach to explain the Croatian...

Table 1: Standard unit root test results

\begin{tabular}{|c|c|c|c|c|}
\hline \multirow[b]{2}{*}{ Variable and test } & \multicolumn{2}{|c|}{ Levels } & \multicolumn{2}{|c|}{ First difference } \\
\hline & Constant & $\begin{array}{c}\text { Constant and } \\
\text { trend }\end{array}$ & Constant & $\begin{array}{c}\text { Constant and } \\
\text { trend }\end{array}$ \\
\hline ADF test & \multicolumn{4}{|c|}{ t-stat. } \\
\hline $\mathrm{CA}$ & -1.373234 & -3.690647 & -10.72338 & -10.83391 \\
\hline LTPS & -3.068337 & 0.006005 & -2.933066 & -5.304565 \\
\hline $\mathrm{D}$ & -1.542579 & -3.499165 & -12.20777 & -12.31657 \\
\hline REER & -2.625039 & -1.548152 & -5.970161 & -6.712613 \\
\hline M4 & -3.907154 & -4.066662 & -7.884917 & -8.673237 \\
\hline PP test & \multicolumn{4}{|c|}{ Adj. t-stat. } \\
\hline CA & -1.373234 & -3.593835 & -11.51255 & -11.60163 \\
\hline LTPS & -3.363331 & 0.829803 & -2.795244 & -5.304565 \\
\hline $\mathrm{D}$ & -1.056061 & -3.279851 & -12.80947 & -13.55647 \\
\hline REER & -2.393210 & -1.561448 & -6.000232 & -6.729829 \\
\hline M4 & -3.915366 & -3.882794 & -8.118709 & -8.730287 \\
\hline KPSS test & \multicolumn{4}{|c|}{ LM-stat. } \\
\hline $\mathrm{CA}$ & 0.844207 & 0.192239 & 0.307608 & 0.117893 \\
\hline LTPS & 0.848064 & 0.278239 & 0.873644 & 0.097589 \\
\hline $\mathrm{D}$ & 0.808705 & 0.199456 & 0.226863 & 0.103752 \\
\hline REER & 0.385172 & 0.270029 & 0.604160 & 0.084551 \\
\hline M4 & 1.058882 & 0.172734 & 0.444075 & 0.107207 \\
\hline
\end{tabular}

Source: Authors' calculations

The unit root tests results in Table 1 show that none of the variables under consideration is integrated of order two I (2). Since all of the observed variables are stationary I ( 0 ) or integrated of order one I (1), we firstly examine the Croatian current account under absorption approach. Therefore, the dependent variable in equation (3) is current account (CA) and independent one is domestic demand in Croatia (D). The estimates are provided in Table 2. 
Table 2: NARDL estimates of the Croatian current account under absorption approach

\begin{tabular}{|c|c|c|c|}
\hline Variable & Estimate & $\mathrm{t}$-value & $p$-value \\
\hline Intercept & $\begin{array}{l}-0.12970 \\
(0.03598) \\
\end{array}$ & -3.605 & 0.000630 \\
\hline $\log (\mathrm{CA})_{t-1}$ & $\begin{array}{l}-1.00902 \\
(0.24236)\end{array}$ & -4.163 & 0.000100 \\
\hline $\log (\mathrm{D})_{t-1}^{+}$ & $\begin{array}{l}-2.13721 \\
(0.58859)\end{array}$ & -3.631 & 0.000579 \\
\hline $\log (\mathrm{D})_{t-1}^{-}$ & $\begin{array}{l}-2.32241 \\
(0.60172)\end{array}$ & -3.860 & 0.000277 \\
\hline$\Delta \log (\mathrm{D})_{t-1}^{-}$ & $\begin{array}{l}1.26568 \\
(0.42549) \\
\end{array}$ & 2.975 & 0.004198 \\
\hline$\Delta \log (\mathrm{D})_{t-2}^{-}$ & $\begin{array}{c}0.63846 \\
(0.36738)\end{array}$ & 1.738 & 0.087282 \\
\hline $\begin{array}{l}\text { Residual standard } \\
\text { error: } 0.03338\end{array}$ & \begin{tabular}{|c} 
Adjusted R-squared: \\
$29.84 \%$ \\
\end{tabular} & $\begin{array}{c}\text { F-statistic: } \\
6.615 \\
\end{array}$ & $\begin{array}{c}\text { p-value: } \\
5.589 \mathrm{e}-05\end{array}$ \\
\hline \multicolumn{4}{|c|}{ Asymmetric Cointegration test (Bounds Test): } \\
\hline Critical values & $\mathrm{I}(0)$ & $\mathrm{I}(1)$ & F statistic \\
\hline $10 \%$ & 3.17 & 4.14 & \multirow{4}{*}{6.614633} \\
\hline $5 \%$ & 3.79 & 4.85 & \\
\hline $2.5 \%$ & 4.41 & 5.52 & \\
\hline $1 \%$ & 5.15 & 6.36 & \\
\hline \multicolumn{4}{|c|}{ Asymmetry statistics } \\
\hline \multicolumn{2}{|c|}{ Wald F-statistic: 4.836384} & \multicolumn{2}{|c|}{$\mathrm{p}$-value: 0.03166624} \\
\hline
\end{tabular}

Source: Authors' calculations

Following the estimates in Table 2, domestic demand in Croatia and Croatian current account are asymmetrically co-integrated. The influence out of domestic demand is significant at usually accepted significance level in short-run as well as in long run. Furthermore, the influence from domestic demand to current account in short-run as well as in long run is more prominent in case of decline in domestic demand comparing to influence out of increase in domestic demand. Nonetheless, there might be an influence from monetary sector to Croatian current account. In order to obtain robust results, three variables representing monetary sector are examined. Therefore, three model specifications are provided. The each model takes into account one monetary variable (Loans to private sector, monetary aggregates M4 and Real effective exchange rate index) while holding domestic demand as the second independent variable in each model. Therefore, the first model specification aims to explain the dynamics in Croatian current account with domestic demand and loans to private sector and the estimates are summarized in Table 3. 
Mile Bošnjak et al. - Monetary and absorption approach to explain the Croatian...

Table 3: NARDL estimates of the relationship between Croatian current account, domestic demand and loans to private sector.

\begin{tabular}{|c|c|c|c|}
\hline Variable & Estimate & $\mathrm{t}$ - value & $\mathrm{p}$ - value \\
\hline Intercept & $\begin{array}{l}-0.13146 \\
(0.03616)\end{array}$ & -3.635 & 0.000598 \\
\hline $\log (\mathrm{CA})_{t-1}$ & $\begin{array}{l}-1.09948 \\
(0.24826)\end{array}$ & -4.429 & $4.35 \mathrm{e}-05$ \\
\hline $\log (\mathrm{D})_{t-1}^{+}$ & $\begin{array}{l}-2.60230 \\
(0.64460)\end{array}$ & -4.037 & 0.000163 \\
\hline $\log (\mathrm{LTPS})_{t-2}^{+}$ & $\begin{array}{c}0.11653 \\
(0.07184)\end{array}$ & 1.622 & 0.110293 \\
\hline $\log (\mathrm{D})_{t-1}^{-}$ & $\begin{array}{l}-2.38685 \\
(0.66716)\end{array}$ & -3.578 & 0.000716 \\
\hline $\log (\mathrm{LTPS})_{t-2}^{-}$ & $\begin{array}{l}-0.04518 \\
(0.14608)\end{array}$ & -0.309 & 0.758232 \\
\hline$\Delta \log (\mathrm{D})_{t-1}^{-}$ & $\begin{array}{c}1.38489 \\
(0.46450)\end{array}$ & 2.981 & 0.004214 \\
\hline$\Delta \log (\text { LTPS })_{t-2}^{-}$ & $\begin{array}{l}0.04820 \\
(0.95368)\end{array}$ & 0.051 & 0.959867 \\
\hline$\Delta \log (\mathrm{D})_{t-3}^{-}$ & $\begin{array}{c}0.46291 \\
(0.38789)\end{array}$ & 1.193 & 0.237646 \\
\hline$\Delta \log (\mathrm{LTPS})_{t-4}^{-}$ & $\begin{array}{c}0.35051 \\
(1.01903)\end{array}$ & 0.344 & 0.732140 \\
\hline $\begin{array}{c}\text { Residual standard } \\
\text { error: } 0.03342\end{array}$ & $\begin{array}{c}\text { Adjusted R-squared: } \\
29.68 \%\end{array}$ & $\begin{array}{c}\text { F-statistic: } \\
4.096\end{array}$ & $\begin{array}{c}\text { p-value: } \\
0.0004259\end{array}$ \\
\hline \multicolumn{4}{|c|}{ Asymmetric Cointegration test (Bounds Test): } \\
\hline Critical values & $\mathrm{I}(0)$ & $\mathrm{I}(1)$ & F statistic \\
\hline $10 \%$ & 3.17 & 4.14 & \multirow{4}{*}{4.095545} \\
\hline $5 \%$ & 3.79 & 4.85 & \\
\hline $2.5 \%$ & 4.41 & 5.52 & \\
\hline $1 \%$ & 5.15 & 6.36 & \\
\hline \multicolumn{4}{|c|}{ Asymmetry statistics } \\
\hline \multicolumn{2}{|c|}{ Wald F-statistic: 16.80451} & \multicolumn{2}{|c|}{$p$-value: 0.0001328319} \\
\hline
\end{tabular}

Source: Authors' calculations

Following the estimates reported in Table 3, asymmetric co-integration is still established and confirmed but the effects from loans to private sector is not found to be significant. The other monetary variable considered in this paper is the variable representing monetary aggregates M4. Table 4 provides the estimates for the model specification where the Croatian current account is the dependent variable while monetary aggregates M4 and domestic demand represent the independent variables. 
Mile Bošnjak et al. - Monetary and absorption approach to explain the Croatian...

Table 4: NARDL estimates of the relationship between Croatian current account, domestic demand and monetary aggregate (M4).

\begin{tabular}{|c|c|c|c|}
\hline Variable & Estimate & t - value & p-value \\
\hline Intercept & $\begin{array}{l}-0.12867 \\
(0.03938)\end{array}$ & -3.267 & 0.001927 \\
\hline $\log (\mathrm{CA})_{t-1}$ & $\begin{array}{l}-1.15701 \\
(0.32452)\end{array}$ & -3.565 & 0.000790 \\
\hline $\log (\mathrm{D})_{t-1}^{+}$ & $\begin{array}{l}-2.58122 \\
(0.83995)\end{array}$ & -3.073 & 0.003370 \\
\hline $\log (\mathrm{M} 4)_{t-2}^{+}$ & $\begin{array}{c}0.06275 \\
(0.16358) \\
\end{array}$ & 0.384 & 0.702820 \\
\hline $\log (\mathrm{D})_{t-1}^{-}$ & $\begin{array}{l}-2.37867 \\
(0.83747)\end{array}$ & -2.840 & 0.006419 \\
\hline $\log (\mathrm{M} 4)_{t-2}^{-}$ & $\begin{array}{l}-0.69209 \\
(0.39518)\end{array}$ & -1.751 & 0.085789 \\
\hline$\Delta \log (\mathrm{CA})_{t-1}$ & $\begin{array}{l}0.38414 \\
(0.21133)\end{array}$ & 1.818 & 0.074878 \\
\hline$\Delta \log (\mathrm{D})_{t-1}^{+}$ & $\begin{array}{l}2.68355 \\
(0.83743)\end{array}$ & 3.205 & 0.002313 \\
\hline$\Delta \log (\mathrm{M} 4)_{t-2}^{+}$ & $\begin{array}{l}-0.91793 \\
(0.26997)\end{array}$ & -3.400 & 0.001301 \\
\hline$\Delta \log (\mathrm{D})_{t-3}^{+}$ & $\begin{array}{l}-1.12742 \\
(0.46879)\end{array}$ & -2.405 & 0.019769 \\
\hline$\Delta \log (\mathrm{M} 4)_{t-4}^{+}$ & $\begin{array}{c}0.43012 \\
(0.26461)\end{array}$ & 1.626 & 0.110102 \\
\hline$\Delta \log (\mathrm{D})_{t-1}^{-}$ & $\begin{array}{l}1.61103 \\
(0.76161)\end{array}$ & 2.115 & 0.039214 \\
\hline$\Delta \log (\mathrm{M} 4)_{t-2}^{-}$ & $\begin{array}{l}2.08280 \\
(0.58964)\end{array}$ & 3.532 & 0.000873 \\
\hline$\Delta \log (\mathrm{D})_{t-3}^{-}$ & $\begin{array}{l}1.49200 \\
(0.71286)\end{array}$ & 2.093 & 0.041249 \\
\hline$\Delta \log (\mathrm{M} 4)_{t-4}^{-}$ & $\begin{array}{c}0.13298 \\
(0.79972)\end{array}$ & 0.166 & 0.868581 \\
\hline $\begin{array}{c}\text { Residual standard } \\
\text { error: } 0.02613\end{array}$ & $\begin{array}{c}\text { Adjusted R-squared: } \\
57.02 \% \\
\end{array}$ & $\begin{array}{c}\text { F-statistic: } \\
7.254 \\
\end{array}$ & $\begin{array}{l}\text { p-value: } \\
5.062 \mathrm{e}-08\end{array}$ \\
\hline \multicolumn{4}{|c|}{ Asymmetric Cointegration test (Bounds Test): } \\
\hline Critical values & $\mathrm{I}(0)$ & $\mathrm{I}(1)$ & F statistic \\
\hline $10 \%$ & 3.17 & 4.14 & \multirow{4}{*}{7.253781} \\
\hline $5 \%$ & 3.79 & 4.85 & \\
\hline $2.5 \%$ & 4.41 & 5.52 & \\
\hline $1 \%$ & 5.15 & 6.36 & \\
\hline \multicolumn{4}{|c|}{ Asymmetry statistics } \\
\hline Wald F-stat & ic: 8.755591 & $\mathrm{p}-\mathrm{va}$ & 37665 \\
\hline
\end{tabular}

Source: Authors' calculations 
Mile Bošnjak et al. - Monetary and absorption approach to explain the Croatian...

The results in Table 4 point out that taking into account monetary aggregates M4 the model improved. The asymmetric co-integration is established and confirmed. Compering to estimates in Table 2, explanatory power of the model presented in Table 4 is almost doubled. Adjusted R-squared for the specification presented in Table 2 amounts 29.84\% while the reported Adjusted R-squared for model specification reported in Table 4 amounts $57.02 \%$. As expected, the influence out of monetary sector is more prominent in a short-run. Hence, the change monetary aggregates M4 significantly influence Croatian balance of payments with delay of two quarters (lag two).

Table 5: NARDL estimates of the relationship between Croatian current account, domestic demand and real effective exchange rate index.

\begin{tabular}{|c|c|c|c|}
\hline Variable & Estimate & $\mathrm{t}$ - value & $\mathrm{p}$ - value \\
\hline Intercept & $\begin{array}{l}-0.1272303 \\
(0.0355545)\end{array}$ & -3.578 & 0.000714 \\
\hline $\log (\mathrm{CA})_{t-1}$ & $\begin{array}{l}-1.0598627 \\
(0.2468084)\end{array}$ & -4.294 & $6.89 \mathrm{e}-05$ \\
\hline $\log (\mathrm{D})_{t-1}^{+}$ & $\begin{array}{l}-2.4781623 \\
(0.6837282)\end{array}$ & -3.624 & 0.000618 \\
\hline $\log (\mathrm{REER})_{t-2}^{+}$ & $\begin{array}{l}-0.0001731 \\
(0.3170656)\end{array}$ & -0.001 & 0.999566 \\
\hline $\log (\mathrm{D})_{t-1}^{-}$ & $\begin{array}{l}-2.2143498 \\
(0.7841212)\end{array}$ & -2.824 & 0.006524 \\
\hline $\log (\mathrm{REER})_{t-2}^{-}$ & $\begin{array}{l}-0.4278856 \\
(0.2174958)\end{array}$ & -1.967 & 0.054019 \\
\hline$\Delta \log (\mathrm{D})_{t-1}^{-}$ & $\begin{array}{c}1.5322131 \\
(0.5839569)\end{array}$ & 2.624 & 0.011137 \\
\hline$\Delta \log (\mathrm{REER})_{t-2}^{-}$ & $\begin{array}{c}1.0916777 \\
(0.8306321)\end{array}$ & 1.314 & 0.194019 \\
\hline$\Delta \log (\mathrm{D})_{t-3}^{-}$ & $\begin{array}{c}0.5833632 \\
(0.3914168) \\
\end{array}$ & 1.490 & 0.141635 \\
\hline$\Delta \log (\mathrm{REER})_{t-4}^{-}$ & $\begin{array}{l}-0.8749961 \\
(0.7955349)\end{array}$ & -1.100 & 0.276006 \\
\hline $\begin{array}{c}\text { Residual standard } \\
\text { error: } 0.0321\end{array}$ & $\begin{array}{c}\text { Adjusted R-squared: } \\
35.13\end{array}$ & $\begin{array}{c}\text { F-statistic: } \\
4.97\end{array}$ & $\begin{array}{l}\text { p-value: } \\
6.155 \mathrm{e}-05\end{array}$ \\
\hline \multicolumn{4}{|c|}{ Asymmetric Cointegration test (Bounds Test): } \\
\hline Critical values & $\mathrm{I}(0)$ & $\mathrm{I}(1)$ & F statistic \\
\hline $10 \%$ & 3.17 & 4.14 & \multirow{4}{*}{4.970462} \\
\hline $5 \%$ & 3.79 & 4.85 & \\
\hline $2.5 \%$ & 4.41 & 5.52 & \\
\hline $1 \%$ & 5.15 & 6.36 & \\
\hline \multicolumn{4}{|c|}{ Asymmetry statistics } \\
\hline \multicolumn{2}{|c|}{ Wald F-statistic: 15.5693} & \multicolumn{2}{|c|}{$\mathrm{p}$ - value: 0.0002205716} \\
\hline
\end{tabular}

Source: Authors' calculations 
Furthermore and following the results in Table 5, the influence is asymmetric pointing out the sizable influence from monetary contraction comparing to its expansion. The third variable representing monetary sector is real effective exchange rate. Therefore, the model specification where the Croatian current account is the dependent variable while real effective exchange rate index and domestic demand represent the independent variables is reported in Table 5.

Following the results in Table 5, the real effective exchange rate helps to explain Croatian current account dynamics. However, the explanatory power of model specification in Table 5 is not as much improved as in case reported in Table 4. Similarly, an effect of real effective exchange rate is effective only in a short-run and at the significance level of $10 \%$. Furthermore, there is an asymmetry in effects out of the real effective exchange rate change. Hence, only appreciation is found to affect Croatian balance of payment while depreciation showed no significant influence. Consistently with assumed by the theory the effects out of appreciation on the Croatian balance of payment are negative All of the estimated model specification passed the diagnostic tests. ${ }^{3}$ As illustrated in Table 2, Table 3, Table 4 and Table 5, to identify the determinants of the balance of payments in Croatia four NARDL model specifications are estimated and tested. Therefore, the obtained results are robust.

\section{Results and discussion}

Following the empirical results from this paper, Croatian current account is quite well explained under monetary and absorption approach. Contrary to findings from Kovačević (2017), the research results from this paper revealed no significant effects from exchange rate to Croatian balance of payments in a long run. Only short-run effects are found to be significant at the $10 \%$ significance level. The best monetary variable to explain Croatian current account is the one representing monetary aggregates M4 over GDP. Due to the high level of financial euroization (Bošnjak, 2018) at the first place, the EUR/HRK exchange rate has been the anchor of the monetary policy in Croatia (Mance et al., 2015; Bošnjak et al., 2016). Consequently, the potential depreciation of the Croatian kuna can hardly provide the desired effects in a long - run. The results support the absorption approach in the case of Croatia and the absorption approach seems to be the one that dominates. Therefore, maintaining the current account equilibrium in Croatia requires the control over domestic demand pointing out the role of fiscal policy in Croatia. The link between fiscal policy and domestic demand in Croatia is established and discussed (Deskar-Škrbić, 2018; Šimović, 2018). Furthermore, the contemporary literature has documented unfavourable effects from fiscal policy in Croatia. Sever

\footnotetext{
$\overline{3 \text { Results available }}$ upon request.
} 
et al. (2011) employed vector autoregression (VAR) approach and provided empirical evidence supporting the inadequate effects from budget expenditures to economic growth in Croatia. In line with Wagner's Law, Bošnjak (2018a) confirmed the effects from government spending to economic growth in Croatia and pointed out the procyclical nature of the relationship. Therefore, fiscal policy measures directed towards another structure of economic growth and external balance in Croatia are inevitable. Moreover, the deficit in the Croatian balance of payments is accompanied with accumulated external debt (Jeločnik et al., 2016) what makes the issue more severe. Šimović and Deskar-Škrbić (2019) pointed out the relatively high public debt level that significantly and adversely affected the effectiveness of fiscal policy in Croatia. The influence out of monetary sector is more prominent in a short-run. However, the increase in money supply improves the Croatian current account. Consequently, the effects of monetary sector on the Croatian current account are not in line with monetary approach. The potential explanation might be that the Croatian exporters are limited to access the necessary financial resources and facilitating financial support to the Croatian exporters might show positive effects on the Croatian current account. The relationship between financial development and trade openness in Croatia is already established (Bilas et al., 2017). The results in this paper clearly point out the existence of liquidity constraints in Croatia. Consistently, Kovačević (2017) pointed out the positive role of foreign direct investments (FDI) in Croatia and neighbouring countries. Based on a firm-level production data over the period of 2005-2009 from China, Huang and Liu (2017) reported that firms with better access to any finance were more likely to export and exported more. The results from this paper are in line with Huang and Liu (2017). The tested analytical framework derived from the competing theories points out the absorption approach as the one that holds in case of Croatia. The influences out of monetary sector are found to be significant but not in line with monetary approach. The reasons may be the assumptions that monetary approach relies on. Frenkel and Johnson (2013) provided extensive overview of the monetary approach to the balance of payments along with its criticism. The criticism was mostly related to the assumptions of the monetary approach. Among the disputed assumption is the one that assumes the existence of a world market price for all goods produced. Another frequently disputed assumption of the monetary approach is the assumption that the demand for money is a stable function of a few macroeconomic variables. Testing the assumption of the monetary approach remains for the further research and presents the limitation of the presented research.

\section{Conclusions}

There are several conclusions that can be drawn out of the research presented in this paper. Firstly, as suggested by the results of the research presented in this paper, the research hypothesis is accepted and the Croatian current account is well explained under monetary and absorption approach. The absorption approach is found to hold 
in case of Croatia. The effects of monetary sector on balance of payments in Croatia were significant but not as assumed by monetary approach. Monetary approach to balance of payments relies on many assumption and some of the assumptions were widely criticized. Therefore, one or more of the corresponding assumption may be violated in the case of Croatia. Secondly, the research results revealed significantly different responses of Croatian current account to positive and negative change in its determinants. NARDL approach employed in this paper revealed nonlinear and asymmetric long run and short-run relationship between Croatian current account and its determinant. Eventually, Croatian current account is the most responsive to change in monetary aggregates M4, among tested variables. Besides monetary aggregates M4, the variables tested in this research are real effective exchange rate index and loans to private sector. The paper points out the potential existence of liquidity constraints in Croatia or limited access of the Croatian exporters to the necessary financial resources. The effects from real exchange rate are found to be in line with theoretical assumptions, but at the $10 \%$ significance and only in a short run. Furthermore and consistently with the absorption approach, the results of the research in this paper indicated the need for fiscal policy measures to establish the control over the domestic demand and external equilibrium in Croatia. The paper provided robust results and pointed out the role of domestic demand and monetary sector for the state of the Croatian current account.

\section{References}

Alexander, S. (1959) "Effects of a Devaluation: A Simplified Synthesis of Elasticities and Absorption Approaches", The American Economic Review, 49 (1), pp. 22-42, Retrieved from: http://www.jstor.org/stable/1808056.

Aristovnik, A. (2008) "Short-Term Determinants of Current Account Deficits: Evidence from Eastern Europe and the Former Soviet Union", Eastern European Economics, Vol. 46, Issue 1, pp. 24-42, doi: 10.2753/EEE00128775460102.

Bahmani, M., Harvey, H., Hegerty, S. W. (2013) "Empirical tests of the MarshallLerner condition: a literature review, Journal of Economic Studies, 40 (3), pp. 411-443, doi: 10.1108/01443581311283989.

Bakker, B. B., Gulde, A. M. (2010) "The Credit Boom in the EU New Member States: Bad Luck or Bad Policies?", International Monetary Fund Working Paper, 10/130, Retrieved from: https://papers.ssrn.com/sol3/papers.cfm?abstract_ id $=1620249$.

Bilas, V., Bošnjak, M. (2015) "Empirical evidence on Heckscher-Ohlin trade theorem: the case of international trade between Croatia and the rest of the European Union member states", Zbornik radova Ekonomskog fakulteta u Rijeci: časopis za ekonomsku teoriju i praksu/Proceedings of Rijeka Faculty of 
Economics: Journal of Economics and Business, Vol. 33, Issue 1, pp. 103-124, Retrieved from: https://hrcak.srce.hr/file/206483.

Bilas, V., Bošnjak, M., Novak, I. (2017) "Examining the Relationship between Financial Development and International Trade in Croatia", South East European Journal of Economics and Business, 12 (1), pp. 80-88, doi: 10.1515/ jeb-2017-0009.

Bošnjak M., Bilas V., Novak I. (2018) "Sustainability of Merchandise Trade Flows between Croatia and Other EU Member States - Panel Cointegration Approach", Panoeconomicus, Advance online publication, pp. 1-22, doi: 10.2298/PAN160409022B.

Bošnjak, M. (2018) "Financial eurization in Croatia and its (non) linear pattern behaviour", Croatian Operational Research Review, 9 (1), pp. 51-62, doi: 10.17535/crorr.2018.0005.

Bošnjak, M. (2018a) "Governments spending and growth nexus with nonlinear adjustments: re-examining the Croatian and Slovenian case", Economic Research-Ekonomska Istraživanja, pp. 1-11. Advance online publication, doi: 10.1080/1331677X.2018.1515644.

Bošnjak, M., Bilas, V., Novak, I. (2016) "Modeling exchange rate volatilities in Croatia", Ekonomski vjesnik/Econviews-Review of Contemporary Business, Entrepreneurship and Economic Issues, 29 (1), pp. 81-94, Retrieved from: https://hrcak.srce.hr/161035.

Chuku, C., Atan, J., Obioesio, F., Onye, K. (2017) "Current Account Adjustments and Integration in West Africa“, Working Paper, No 287. Retrieved from: https:// www.afdb.org/fileadmin/uploads/afdb/Documents/Publications/WPS_No_287_ Current_Account_Adjustments_and_Integration_in_West_Africa_A.pdf.

Davis, J. S., Mack, A., Phoa, W., Vandenabeele, A. (2016) "Credit booms, banking crises, and the current account", Journal of International Money and Finance, Vol. 60, pp. 360-377, doi: 10.1016/j.jimonfin.2015.09.008.

Deskar-Škrbić, M. (2018). Dynamic effects of fiscal policy in Croatia: confronting New-Keynesian SOE theory with empirics. Zbornik radova Ekonomskog fakulteta u Rijeci: časopis za ekonomsku teoriju i praksu, Vol. 36, Issue 1, pp. 83-102, doi: 10.18045/zbefri.2018.1.83.

Ekinci, M. F., Erdem, F.P., Kilinc, Z. (2015) "Credit growth, current account and financial depth", Applied Economics, Vol. 47, Issue 17, pp. 1809-1821, doi: 10.1080/00036846.2014.1002897.

Elhaddadi, M., Karim, M. (2017) "Monetary Approach to the Balance of Payments: A Moroccan Case Study“, Applied Economics and Finance, Vol. 4, Issue 5, pp. 94-100, doi: 10.11114/aef.v4i5.2629.

Fasanya, I. O., Olayemi, I. A. (2018) "Balance of payment constrained economic growth in Nigeria: How useful is the Thirlwall's hypothesis?", Future Business Journal, 4 (1), pp. 121-129, doi: 10.1016/j.fbj.2018.03.004. 
Frenkel, J. A., Johnson, H. G. (2013) "The Monetary Approach to the Balance of Payments (Collected Works of Harry Johnson)", Routledge.

Harberger, A. C. (1950) "Currency Depreciation, Income and the Balance of Trade“, Journal of Political Economy, Vol. 58, pp. 47-60, doi: 10.1086/256897.

Huang, X. B., Liu, X. L. (2017) "How do firms finance their exports? - evidence from China. Journal of International Trade \& Economic Development, 26 (2), pp. 154-173, doi: 10.1080/09638199.2016.1227869.

Impavido, G., Rudolph, M. H., Ruggerone, M. L. (2013) "Bank Funding in Central, Eastern and South Eastern Europe Post Lehman: A "New Normal"?", (No. 13-148, International Monetary Fund, Retrieved from: https://www.imf. org/external/pubs/ft/wp/2013/wp13148.pdf.

Jeločnik, M., Zubovic, J., \& Djukic, M. (2016). Implications of globalization on growing external debt in eight transition economies. In Global Perspectives on Trade Integration and Economies in Transition, pp. 80-104, IGI Global.

Kauko, K. (2014) "How to foresee banking crises? A survey of the empirical literature“, Economic Systems, Vol. 38, Issue 3, pp. 289-308, doi: 10.1016/j. ecosys.2014.01.001.

Khadaroo, A. J. (2016) "Current Account Deficit in Mauritius: Risks and Prospects", South African Journal of Economics, Vol. 84, Issue 1, pp. 109-128, doi: 10.1111/ saje.12102.

Khalid Yousif, F. M., Attahir Musa, A. M. (2017) "The Determinants Factors of Balance of Payments: An Investigation from Sudan through the Period 19802016", American Scientific Research Journal for Engineering, Technology, and Sciences (ASRJETS), Vol. 38, Issue 1, pp. 265-282. Retrieved from: http:// asrjetsjournal.org/index.php/American_Scientific_Journal/article/view/3343.

Kovačević, R. (2017) "Current Account determinants in Southeast European (SEE) countries - panel approach", Zbornik Radova Ekonomskog Fakulteta u Rijeci, Vol. 35, Issue 2, pp. 391-424, doi: 10.18045/zbefri.2017.2.391.

Mance, D., Žiković, S., Mance, D. (2015) "Econometric Analysis of Croatia's Proclaimed Foreign Exchange Rate", South East European Journal of Economics and Business, Vol. 10, No. 1, pp. 7-17, doi: 10.1515/jeb-2015-0001.

Meniago, C., Hinaunye Eita, J. (2017) "The effects of exchange rate changes on Sub-Saharan Africa trade", International Journal of Sustainable Economy, Vol. 9, Issue 3, pp. 213-230, doi: 10.1504/IJSE.2017.085065.

Obadić, A., Globan, T. and Nadoveza, O. (2014) "Contradicting the Twin Deficits Hypothesis: The Role of Tax Revenues Composition", Panoeconomicus, Vol. 6, pp. 653-667, doi: 10.2298/PAN1406653O.

Ozgur, G., Memis, E. (2017) "Macroeconomic imbalances and the eurozone crisis: the impact of credit expansion on asset prices", Review of Keynesian Economics. Vol. 5, Issue 3, pp. 459-480. Retrieved from: https://www. elgaronline.com/abstract/journals/roke/5-3/roke.2017.03.07.xml. 
Pesaran, M. H., Shin, Y., Smith R. J. (2001). "Bounds Testing Approaches to the Analysis of Level Relationships", Journal of Applied Econometrics, Vol. 16, pp. 289-326, doi: 10.1002/jae.616.

Polak, J. J. (1957) "Monetary Analysis of Income Formation and Payments Problems", IMF Staff Papers, Vol. 6, No. 1, pp. 1-50, doi: 10.2307/3866128.

Robinson, J. (1937) "The Foreign Exchanges", in Robinson J., Essays in the Theory of Unemployment, London: Macmillan.

Sever, I., Drezgić, S., Blažić, H. (2011) "Budget spending and economic growth in Croatia: Dynamics and relathionships over the past two decades", Zbornik radova Ekonomskog fakulteta u Rijeci - Proceedings of Rijeka Faculty of Economics, Vol. 29, No. 2, pp. 291-331. Retrieved from: https://hrcak.srce. $\mathrm{hr} / 75202$.

Shahid Hassan, M., Wajid, A., Kalim, R. (2017) "Factors affecting trade deficit in Pakistan, India and Bangladesh", Econnomia Politica, Vol. 34, Issue 2, pp. 283-304, doi: 10.1007/s40888-017-0053-7.

Shin, Y., Yu, B., Greenwood-Nimmo, M. (2011) "Modelling asymmetric cointegration and dynamic multipliers in a nonlinear ARDL framework", SSRN Electronic Journal, doi: 10.2139/ssrn. 1807745 .

Šimović, H. (2018)Impact of public debt sustainability on fiscal policy in Croatia. Acta Oeconomica, Vol. 68, Issue 2, pp. 231-244, doi: 10.1556/032.2018.68.2.3.

Šimović, H., Deskar-Škrbić, M. (2019) "Fiscal Policy and European Semester in Croatia: Why Should We Focus on Public Debt?", In Policy-Making at the European Periphery, pp. 169-186, Palgrave Macmillan, Cham.

Thirlwall A.P. (1980) "The Absorption Approach to the Balance of Payments. In: Balance-of-Payments Theory and the United Kingdom Experience", Palgrave, London, doi: 10.1007/978-1-349-16246-8_4.

Topalli, N., Dogan, I. (2016) "The structure and sustainability of current account deficit: Turkish evidence from regime switching", Journal of International Trade \& Economic Development, Vol. 25, Issue 4, pp. 570-589, doi: 10.1080/ 09638199.2015.1090472.

Unger, R. (2017) "Asymmetric credit growth and current account imbalances in the euro area", Journal of International Money and Finance, Vol. 73, pp. 435-451, doi: 10.1016/j.jimonfin.2017.02.017.

Wollmershäuser, T. (2016) "Exchange Rate Policy in Croatia", In CESifo Forum, Vol. 17, No. 1, pp. 8-11, München: ifo Institut-Leibniz-Institut für Wirtschaftsforschung an der Universität München. Retrieved from: https:// www.econstor.eu/handle/10419/166631.

Zakharova, D. (2008) "One-Size-Fits-One: Tailor-Made Fiscal Responses to Capital Flows", International Monetary Fund, doi: 10.5089/9781451871272.001. 


\title{
Monetarni i apsorpcijski pristup na primjeru tekućeg računa platne bilance Republike Hrvatske
}

\author{
Mile Bošnjak ${ }^{1}$, Ivan Novak ${ }^{2}$, Ante Krišto ${ }^{2}$
}

\begin{abstract}
Sažetak
U radu se istražuju odrednice kretanja tekućeg računa platne bilance Republike Hrvatske primjenom monetarnog apsorpcijskog pristupa platnoj bilanci. Glavna hipoteza rada pretpostavlja da se tekući račun platne bilance u Republici Hrvatskoj može objasniti unutar analitičkog okvira koji se temelji na monetarnom $i$ apsorpcijskom pristupu analizi platne bilance. U radu se primjenjuje suvremeni ekonometrijski pristup nelinearne auto-regresije $s$ distribuiranim pomacima (NARDL) koji uzima u obzir nelinearnu $i$ asimetričnu prirodu odnosa između tekućeg računa platne bilance u Republici Hrvatskoj i njegovih determinanti. Procijenjeni rezultati na tromjesečnom uzorku podataka od prvog tromjesečja 2000. do drugog tromjesečja 2017. godine podupiru glavnu istraživačku hipotezu i potvrđuju da se tekući račun platne bilance Republike Hrvatske može objasniti korištenjem analitičkog okvira utemeljenog na monetarnom $i$ apsorpcijskom pristupu. Domaća potražnja, realni tečajni indeks, te krediti privatnom sektoru i monetarni agregati M4 testirani su kao odrednice tekućeg računa platne bilance Republike Hrvatske. Utvrđeno je da monetarni agregati M4 imaju najveću objašnjavajuću snagu među istraženim monetarnim varijablama. Glavni nalazi ovog rada upućuju na potrebu za mjerama fiskalne politike $i$ uklanjanje ograničenja hrvatskim izvoznicima u pristupu likvidnim sredstvima kako bi se uspostavila vanjska ravnoteža.
\end{abstract}

Ključne riječi: asimetrična kointegracija, tekući račun platne bilance, monetarni pristup, apsorpcijski pristup, Hrvatska

JEL klasifikacija: C22, C51, F14, F43

${ }^{1}$ Docent, Sveučilište u Zagrebu, Ekonomski fakultet, Trg J. F. Kennedyja 6, 10000 Zagreb, Hrvatska. Znanstveni interes: međunarodna ekonomija, nelinearna ekonometrija, primijenjena ekonometrija, neuronske mreže.

${ }^{2}$ Demonstrator - back.oec., Sveučilište u Zagrebu, Ekonomski fakultet, Trg J. F. Kennedyja 6, 10000 Zagreb, Hrvatska. Znanstveni interes: međunarodne financije. 